\title{
ОСОБЛИВОСТІ РОБОТИ НАД ІНТОНАЦЙНОЮ ВИРАЗНІСТЮ УСНОГО МОВЛЕННЯ МОЛОДШИХ ШКОЛЯРІВ НА УРОКАХ ЧИТАННЯ
}

\begin{abstract}
Кравцова I. А. Особливості роботи над інтонаційною виразністю усного мовлення молодших школярів на уроках читання.

Важливою умовою високої культури усного мовлення $є$ оволодіння системою мови в усіх іiі аспектах, або ярусах, - звуковому, зокрема інтонаційному, граматичному і стилістичному. Досліджуючи питання звукової й інтонаційної виразності усного мовлення, методисти визначають нерозривний зв'язок між роботою з розвитку усного мовлення та формуванням навичок виразного читання, що грунтуються на розвитку в учнів мовленнєвого слуху. Цілеспрямована робота над виразним читанням й усним мовленням несе учням радість і задоволення. Для вчителів початкових класів очевидним є те, що усвідомлена робота над важливими засобами виразності - запорука усвідомленого мовлення та виразності рідної мови.
\end{abstract}

Ключові слова: інтонаційна виразність, усне мовлення, вразне читання, засоби виразності.

Кравцова И. А. Особенности работы над интонационной выразительностью устной речи младших школьников на уроках чтения.

Важным условием высокой культуры устной речи является овладение системой языка во всех его аспектах, или ярусах, - звуковом, в том числе интонационном, лексическом, грамматическом и стилистическом. Исследуя вопрос звуковой и интонационной выразительности устной речи, методисты устанавливают неразрывную связь между работой по развитию устной речи и формированием навыков выразительного чтения, основанных на развитии у учеников речевого слуха. Целеустремленная работа над выразительным чтением и устной речью несет ученикам радость и удовольствие. Для учителя начальных классов очевидным является то, что осознанная работа над важными средствами выразительности - залог осмысленной речи и выразительности родного языка.

Ключевые слова: интоннационная выразительность, устная речь, выразительное чтение, средства выразительности.

Kravtsova I. A. Peculiarities of classroom activities to intonational expressiveness in oral speech oh junior pupils.

The important condition of high culture of verbal speech is a mastering the system of language in all aspects or tiers - sound, including intonational, lexical, grammatical and stylistic. Investigating the question of sound and intonational expressiveness of verbal speech methodists establish an indissoluble connection between work on development of verbal speech and forming of expressive reading skills based on students' vocal hearing. The purposeful work on the expressive reading and verbal speech brings students joy and pleasure. Deliberate work on important facilities of expressiveness as a pledge of intelligent speech and expressiveness of the mother tongue is obvious to the elementary school teacher.

Key words: intonational expressiveness, oral speech, reading, expressive means.

Сучасна лінгвістика дедалі частіше звертається до всебічного й поглибленого аналізу усного мовлення, його особливостей у комунікативному плані, виявлення, зокрема, його експресивності, дієвості.

Найважливішою передумовою високої культури усного мовлення, як підкреслював академік І. К. Білодід, є оволодіння системою мови в усіх іiі шарах, або ярусах, - звуковому, у тому числі інтонаційному, лексичному, 
граматичному i стилістичному. Мовознавцями i психологами зроблено багато у вивченні найменше дослідженої ланки - інтонації мовлення (праці В. О. Артемова, Б. В. Бєляєва, Л. А. Близниченка, О. Ф. Пилипенко, А. Й. Багмут). Паралельно розпочато фоностилістичні дослідження. Це дало змогу вивчати засоби звукової організації мовлення, що допомагають найбільш вдало висловлювати думки і впливати на слухачів. Завдяки цим дослідженням можна зробити наукові узагальнення про структуру мови, iii динаміку й багатогранні функції комунікації. Вони дають підстави для створення наукових рекомендацій щодо суспільної практики в усіх сферах життя [1, с. 8].

Досліджуючи питання звукової та інтонаційної виразності усного мовлення, методисти встановлюють нерозривний зв'язок між роботою 3 розвитку усного мовлення і формуванням навичок виразного читання, «які грунтуються на розвитку в учнів мовного слуху, що виявляється в умінні розрізняти наголошені і ненаголошені склади, інтонувати речення різних структур, підвищувати й понижувати голос, прискорювати й уповільнювати темп мовлення, робити логічний наголос у реченні» [6, с. 69].

Читання - важлива ланка у формуванні виразності усного мовлення учнів, а звукова виразність усного мовлення - необхідна умова виразності читання.

Учитель не тільки вдосконалює у школярів мовний слух і звукову виразність мовлення, а й готує їх до сприймання та глибокого розуміння художніх творів. Завдяки виразному читанню текстів учні краще засвоюють художні засоби, мовні звороти, нові слова і синтаксичні конструкції. Забезпечується безпосередній зв'язок між уроками мови та читання. Як справедливо підкреслюється у працях психологів і методистів М. І. Жинкіна, О. М. Леонтьєва, Г. П. Фірсова, питання звукової та інтонаційної виразності стосується як усного, так і писемного мовлення. Читання можна розглядати як процес, у певному розумінні зворотний письму. Те, що для читання є початком роботи, для письма є їі кінцем. Але інтонаційний компонент в обох випадках виконує дуже важливу роль. Той, хто читає, повинен вичитати ту інтонацію, яка вписана в текст автором. Без цього неможливе правильне прочитання й розуміння тексту.

Якщо учні матимуть розвинене мовне чуття, глибоко розумітимуть засоби виразності мови, відтінки смислу в межах того самого речення, рівень грамотності їхнього письма підвищиться.

Уважність до власного мовлення виробляється у процесі спостереження за мовою інших. Учні користуються розмовною мовою ще задовго до вступу в школу. У школі вони починають усвідомлювати мову як предмет шкільної програми, як засіб спілкування, як науку. Школярі починають свідомо вчити те, що вони засвоїли беззастережним наслідуванням; вони нерідко 3 подивом дізнаються, що слова можуть існувати самі по собі, без предметів і явищ, які вони позначають, можуть 
змінювати свою форму, взаємозамінюватися; що багато слів, якими вони звикли називати навколишні предмети і явища, не літературні; що замість них треба вживати інші, часто зовсім незнайомі для них слова. Усе це створює сприятливі умови для виховання уважності в учнів до власного мовлення.

На жаль, ці можливості використовуються в школі зовсім мало. Синтаксис усної мови, будова речень майже не виправляється, унаслідок чого виробляється своєрідна спрямованість їхнього усного і писемного мовлення. На одних уроках, за одних умов вони уважні до своєї мови, на інших уроках і за інших умов - байдужі. Від одного й того ж учня можна почути досконалу і недосконалу мову.

За браком спеціальної методичної літератури та відповідно підготовлених учителів часом спостерігається вузький, утилітарний підхід до поставлених навчальних завдань, невиправданий страх переобтяжити учнів вправами із звукової виразності усного мовлення.

Якби й усні відповіді оцінювалися за кількістю помилок (на інтонування, вимову, наголос тощо), то загальна оцінка 3 мови була б значно нижчою. В усному мовленні учнів більше відхилень від норми, ніж у писемному. За висловом відомого англійського письменника Бернарда Шоу, є 50 способів сказати «так», 500 способів сказати «ні» - і тільки один спосіб це написати. «Це просте слово можна вимовити на тисячу різних ладів», - зауважує видатний майстер слова І. Л. Андроников.

Як привчати дітей до того, щоб за вимовленими словами вони бачили життя, як навчити їх яскраво уявляти картини, події, предмети, про які мовиться, і виявляти своє ставлення до них? Для цього треба розвивати спостережливість, пам'ять, емоційну чутливість, мовний слух, тренувати мовленнєвий апарат, створювати такі навчальні ситуації, щоб в уяві дітей виникали умови реального спілкування. Вони повинні знати й основні якості мовлення: змістовність, виразність, впливовість тощо. Нагода для цієї роботи є на кожному уроці.

Виняткове значення в навчальному процесі має виразне читання як для поглиблення розуміння змісту твору, так і для розвитку емоцій, уяви, виховання естетичних почуттів. Для того, щоб навчити дітей виразного читання, учитель має сам добре ним володіти. Виразного, емоційного читання від учнів можна вимагати тоді, коли твір глибоко проаналізований, усвідомлений його ідейний зміст.

Виразне читання - це мистецтво читання вголос, за якого яскраво виражаються думки, почуття автора, вкладені у твір, власне ставлення до прочитаного. Виразне читання $є$ ключем до розуміння тексту і водночас грунтується на його усвідомленні, а значить, на глибокому літературному аналізі. Оволодіння навичками виразного читання варто починати 3 усвідомлення його найважливіших складників: 
- техніки мовлення - роботи над голосом, дикцією, диханням, орфоепією;

- логіки мовлення - усвідомлення логічного наголосу, пауз, темпу, інтонаціі;

- емоційно-образної виразності - розвитку творчого бачення, розуміння авторського підтексту, використання міміки, жестів [4, с. 36].

Ще Демокріт говорив, що ні мистецтво красномовства, ні мудрість не можуть бути досягнуті, коли не вчитися їх. Учитель насамперед має усвідомлювати, «чого треба навчати, у якій послідовності і як».

Навички виразності усного мовлення прищеплюються дітям до певної мірі ще в дошкільному і молодшому шкільному віці.

Одним із найбільш важливих показників культури усного мовлення $\epsilon$ виразність. Виразність як якість мовлення i читання тісно пов'язана 3 мисленням. Гарне читання - це шлях до гарного мовлення.

Ознайомлення 3 інтонаційною виразністю усного мовлення варто починати в 2 класі із засвоєння принципу словесної дії, дотримання якого виробляє почуття відповідальності за вимовлене слово. Словесна дія - це дуже важливий прийом активізації, який, 3 одного боку, підвищує осмисленість і виразність мовлення, а 3 другого - загострює увагу слухачів i тим самим сприяє запам'ятовуванню почутого. «Говорити - значить діяти», - підкреслював відомий театральний педагог К. С. Станіславський. Навіть перші дитячі «Ма! Ма!» залежно від ситуації, відзначає психолог M. I. Жинкін, можуть бути різними діями: дитина кличе маму, просить у неї захисту, благає сісти поруч та ін. Уже у дворічної дитини мовленнєвий вчинок розрахований на управління ситуацією.

Видатні педагоги В. П. Острогорський, К. Д. Ушинський, С. Русова, М. О. Рибникова, В. О. Сухомлинський наголошували на тому, що вчитель повинен постійно стежити не лише за змістом свого усного мовлення, його лексико-граматичним оформленням, а й за ритмомелодійним ладом, розвивати здатність свого голосу передавати найтонші відтінки думок і почуттів. Це дає змогу володіти увагою аудиторії. «Я зробився справжнім майстром тільки тоді, коли навчився говорити «Іди сюди» 3 15-20 відтінками», - писав А.С. Макаренко [3, с. 263].

Учителю слід нагадувати дітям про те, що всі засоби виразності тісно пов'язані між собою, i, щоб наше мовлення було дійсно виразним, необхідно вміти користуватися всіма засобами.

Спостереження показують, що мовлення молодших школярів відзначається бідністю інтонаційного малюнка, часто неправильно вибраним тоном, недостатньою гучністю мовлення - основними недоліками темпу читання і висловлювання.

Такі засоби виразності мовлення, як мелодика, основний тон висловлювання, гучність, темп, визначаються головним чином змістом і основною думкою, настроєм мовця, авторським задумом. Тому робота над 
ними може включатися в аналіз тексту. Однак недостатньо працювати лише над текстами для читання, уміщеними в підручнику. Необхідно приділяти особливу увагу спеціальним вправам, які передбачають активну мовленнєву діяльність учнів, навчають вибору необхідних засобів виразності усного мовлення.

Слід показати дітям залежність вибору тих чи тих засобів виразності від змісту й основної думки висловлювання, поступово формувати в них уміння самостійно добирати необхідні для певного висловлювання мелодику, тон, гучність, темп, виразність читання віршів, переказування прози, зокрема казки.

Навчати мелодики мовлення найкраще на невеликих віршах, які учні легко вивчають напам'ять.

Слід також привчати учнів правильно використовувати основний тон. Цей засіб виразності слід ураховувати не лише під час читання, а й в усному переказуванні текстів, під час створення власних зв'язних усних висловлювань.

Під час читання уривків із казок учителю слід доводити дітям, що залежно від змісту висловлювання, почуттів і настрою мовця, текст може бути вимовлений найрізноманітнішим тоном: прохально, жалібно, зневажливо, суворо, із здивуванням, схваленням, осудом, 3 радістю, смутком, тривогою, іронією тощо. Учні пригадують прислів'я: «Те ж слово, але не так мовиться», згадують про те, яке важливе значення має тон мовлення у спілкуванні між людьми: іноді людина говорить ніби зовсім необразливі слова, але співрозмовник ображається.

Робота над тоном висловлювання тісно пов'язана 3 роботою над гучністю. Уміння говорити 3 нормальною гучністю $є$ дуже важливою комунікативною якістю мовлення.

Інтонаційним засобом виразності $є$ також темп мовлення. Вибір темпу визначається в основному змістом, призначенням, задумом висловлювання, а також жанром твору.

Цілеспрямована робота над виразністю читання й усного мовлення принесе дітям радість і задоволення. Для вчителя ж є очевидним, що свідома робота над важливими засобами виразності - запорука осмисленого мовлення, усвідомлення виразності рідної мови.

Інтонаційна невиразність усних розповідей i відповідей учнів пояснюється тим, що вони не володіють навичками публічного мовлення. Для вдосконалення виразності усного мовлення словесник може використовувати будь-яку нагоду, комплексно розв'язуючи навчальновиховні завдання.

Сприймання й усвідомлення учнями навчальної інформації залежить від досконалості мовлення як учителя, так і учнів. Недостатнє засвоєння навчального матеріалу значною мірою $є$ наслідком невідповідності рівнів 
володіння мовленням учителів і учнів. Отже, висока культура усного мовлення - одна з передумов ефективності навчально-виховного процесу.

\section{Література}

1. Джежелей О. В. Позакласне читання. 1-4 класи : [методичні поради, розробки уроків] / О. В.Джежелей, А. А.Смець - Х. : Вид. група «Основа», 2007. - 176 с.

2. Іванова Л. Літературна компетентність молодшого школяра / Л. Іванова // Початкова освіта. 2005. - №38. - C. $2-5$.

3. Макаренко А. С. Вибрані твори / А. С. Макаренко. - Т. 2. - К. : Рад. школа, 1984.

4. Олійник Г. А. Виразне читання. Основи теорії / Г. А. Олійник. - Тернопіль : Навч. книга - Богдан, 2007. $-224 \mathrm{c}$.

5. Пелешок Е. Робота над засобами виразності на уроках читання / Е. Пелешок, Т. Шевчук // Початкова школа. - 1998. - №12. - С. 12-14.

6. Програми для середньої загальноосвітньої школи : 1-4 класи // Початкова школа. - 2006. -432 с.

Стаття надійшла до редакції 7.11.2011 р. 